\title{
A study on the effect of human resource empowerment on productivity: Evidence from Indone- sian higher education
}

\author{
Nuryanto $^{a}$ and Zulfikar Bagus Pambuko ${ }^{b^{*}}$
}

${ }^{a}$ Department of Informatics Engineering, Universitas Muhammadiyah Magelang, Magelang, Indonesia ${ }^{b}$ Department of Islamic Economics Law, Universitas Muhammadiyah Magelang, Magelang, Indonesia

CHRONICLE ABSTRACT

\begin{tabular}{l} 
Article history: \\
Received: June 11, 2019 \\
Received in revised format: June \\
292019 \\
Accepted: July 4, 2019 \\
Available online: \\
July 4, 2019 \\
\hline Keywords: \\
Human resources \\
Muhammadiyah higher education \\
Productivity \\
Empowerment \\
Structural equation model \\
Indonesia
\end{tabular}

\section{Introduction}

At the turn of the $20^{\text {th }}$ century, modernism is part of an Islamic movement in Indonesia. This aims to purify Indonesian Islam from heterodox practice. In 1912, Muhammadiyah institution was established as an expression of the modernist movement, wished to dispose the 'superstitions' related to some traditional practices. At present, Muhammadiyah with their Islamic ideology is significantly involved in education, health care, orphanages, and other social services (Rabasa, 2005). For Muhammadiyah, education becomes the most effective media of da'wah Islamiyah (known as Islamic dissemination), both formal and informal institutions. To date, Muhammadiyah has managed 4,623 Quranic teaching, 2,252 primary schools, 1,111 junior high schools, 1,293 senior high schools, 67 Islamic boarding schools and * Corresponding author.

E-mail address: zulfikar.bp@ummgl.ac.id (Z. B. Pambuko)

C 2019 by the authors; licensee Growing Science, Canada doi: $10.5267 /$ j.msl.2019.7.008 
171 higher education in Indonesia (Amar \& Setiawan, 2018; Andriani et al., 2019; RA, 2006). Those institutions are managed centrally in the form of education policy by the head of Muhammadiyah. Therefore, the hope of its contribution to a society increasingly a concern for the public, not least in the higher education level. Muhammadiyah Higher education, which is currently spread throughout Indonesia must implement the Catur Dharma, namely teaching, research, community service, and Islamic dissemination (Zain et al., 2017). The four obligations must go hand in hand and support each other in order to realise the vision, mission, and goals. Especially for Islamic dissemination, the application is merged with three other obligations. The question that arises is how well the Muhammadiyah Higher education can manage the resources to fulfil those obligations. In this context, the study is needed to measure performance, primarily related to productivity. The issue of productivity is very important because the higher education is faced with two difficult choices, survival or death, primarily aimed at Muhammadiyah Higher education which is managed autonomously without intervention from the head office. Given the governance autonomy, Muhammadiyah higher education management must be able to recognise the potential of their human resources and then maximise it.

In performance measurement, Muhammadiyah higher education is treated the same as a productive unit, which requires input to achieve a certain level of output. This treatment can be used as anomaly to create excellence, such as the number of professors, lecturer academic level, research work, and the quality of publications (Bolli \& Farsi, 2015; Daszkiewicz et al., 2008; Flegg et al., 2003, 2004; Halkos et al., 2011; Ulutaş, 2011). In addition, during the observation period, the productivity of Muhammadiyah higher education, showing the same trend from the teaching and research perspective. However, based on the productivity score of both, the research activity is better than teaching $(1.160>0.962)$. Its means, research activity has increased their productivity by $16.0 \%$, while teaching is regressed by $3.8 \%$ during the observation period (Fig. 1). For research activity, the highest productivity was achieved in 2014 by $47.2 \%$ although 2015 experienced a relatively large decline, about $9.2 \%$ from the previous period and rebound in the next two years. Then for teaching activities, productivity is regress from 2014 until 2016, but in 2017 experienced the improvements by $8.8 \%$.

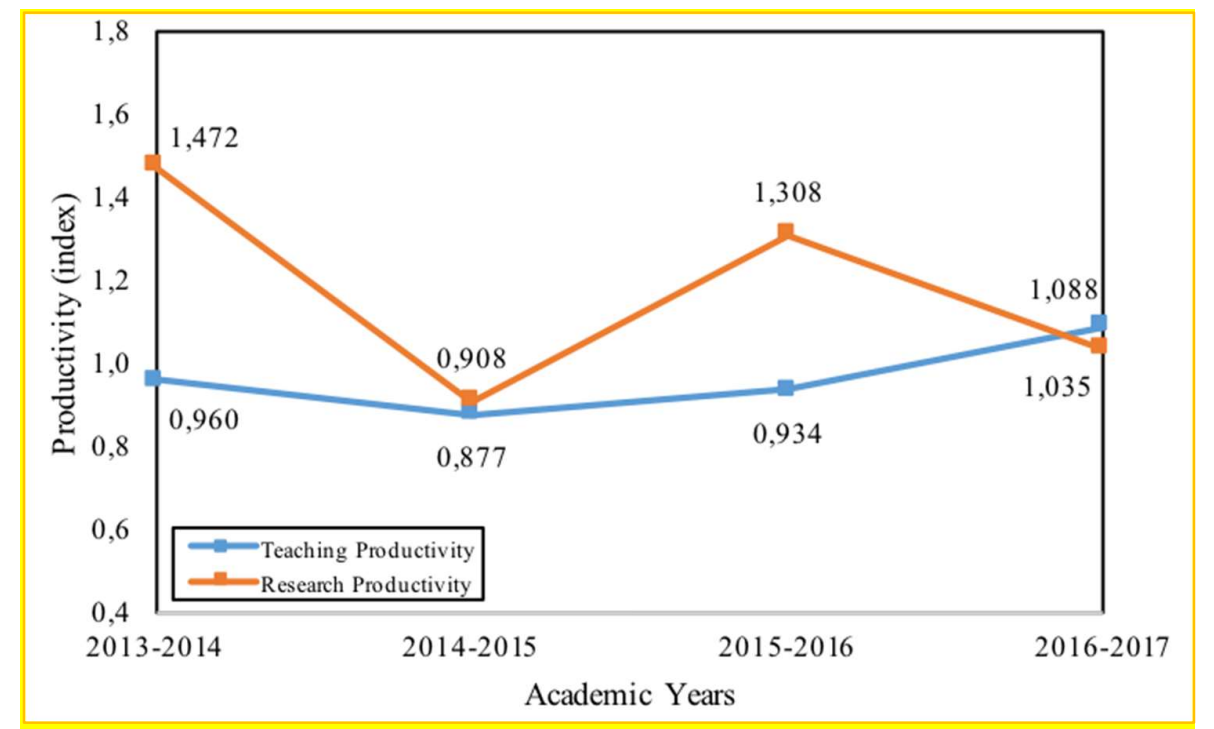

Fig. 1. The Overview of Muhammadiyah Higher Education's Productivity

The purpose of the present research is to examine the impact of human empowerment through information technology, organizational knowledge and cultural dimensions on the productivity of Muhammadiyah higher education in the region of Indonesia. The rest of paper is as follows: Section two indicates the literature context, section three defines the variables of the study. Section four provides the comprehensive detail about research methodology being adopted. Section five provides the results and discussion, while last section covers the conclusion and future recommendations. 


\section{Literature Review}

Many researchers have studied the productivity analysis of higher education. However, few have discussed the productivity analysis of human resources in higher education, particularly in eliminating the financial aspect. A study in 45 British universities found that the efficiency in the UK fluctuated with a positive tendency. The most striking increase occurred in 1987/1988 and 1990/1991 and productivity was increased by $51.5 \%$ (Flegg et al., 2003). The study in 35 Australian universities also found that annual productivity growth averaged $3.3 \%$ and was influenced by technological progress. However, separate analysis of productivity for research and teaching showed an increase in research productivity related to the improvement of technical changes and scale efficiency. The teaching also contributed and it was influenced by technological progress despite the decrease in technical efficiency (Worthington \& Lee, 2008). The study at 12 universities in Switzerland in 1995 - 2007 found that productivity levels had a negative trend, especially after the 2000s where the education system in Switzerland adopted the Bologna Accords (Bolli \& Farsi, 2015). Another case at 32 Colombian public universities found that Tolima, Caldas and UNAD become the best-performing universities, while Universidad del Pacifica was the worst performer. Based on the Malmquist index, The Universidad de La Guajira showed significant improvement in technical efficiency between 2011 and 2012 (Visbal-Cadavid et al., 2017). Those studies also supported by the study at public higher education institutions (HEIs) in 7 European countries which found that HEI productivity rose by $4 \%$ annually. There are considerable national differences, with German, Italian and Swiss HEIs performing better than the other countries examined (Parteka \& WolszczakDerlacz, 2013). The newest study in higher education was performed by Wolszczak-Derlacz (2018) at Europe and U.S. which found that the productivity was progressed in European higher education while the U.S. higher education was regressed in productivity.

In recent years, Akbari \& Ghaffari (2017) examined the impact of key factors under the title of knowledge management for enhancing the HR in water and waste company in Azerbaijan and Iran. For this purpose, they collected a sample in selected company with the help of questionnaire approach while targeting the various factors like information technology, cultural dimensions, knowledge management and human resource development. Findings of the study were extracted while using the Smart PLS version two through structural equation modelling approach. Findings of their study explains the fact that key various have their significant effects while increasing and enhancing the development of human resource in selected company. In addition, as per the practical implication, their study recommended the fact that organizational managers should be provided with the better articulation of shared values for the development of strategic decision making in their business for the development of human resource. Meanwhile, their paper is observed as among the initial contribution which are integrating the targeted exogenous variables with the human resource dimension. Research study conducted by Hill and Stewart (2000) observed the development of human resource in the small business firms. Their study was based on the case study approach while targeting the three small business firms in the region of England. While applying the human resource development model, it was observed the values and characteristics of small business firms while providing some future recommendations as well. Additionally, in recent years, numerous studies have also focused on the notion of higher education and its performance through various means. Notable studies are performed by Abankina et al. (2012); Crookes (2017); Fernandes and Fernandes (2018) and Sukirno and Siengthai (2011).

Based on the literature review, this study is focused on productivity analysis of Human Resources in the Muhammadiyah Higher education. It is a preliminary study of four obligations' evaluation; namely teaching, research, community service, and Islamic dissemination. Unlike the previous research, this study does not include financial aspects due to it focuses on the quality of human resources. Therefore, based on a combination of inputs and outputs from the previous research, the following hypotheses are developed to examine the relationship between human resource empowerment and higher education productivity: 
H1: Empowerment of human resource in terms of information technology is beneficial to increase the productivity the of higher education.

H2: Empowerment of human resource in terms of cultural dimensions is beneficial to increase the productivity the of higher education.

H3: Empowerment of human resource in terms of organizational knowledge is beneficial to increase the productivity the of higher education.

\section{Research Methodology}

As stated earlier, the purpose of this research is to examine the relationship between human resource development through information technology, knowledge dimensions, cultural perspective of human resources and productivity of higher educational in the region of Indonesia. For the collection of the relevant data, two step approach is adopted. In the very first step, questionnaire is developed through adopting various items of information technology, knowledge dimensions for human resources development and cultural perspective of HR development with the productivity indicators of higher education. For the three latent variables of HR development, eight items for each are added in the questionnaire as measured on the five-point Likert scale. These points are ranging from strongly disagree to strongly agree with a code of one to five respectively. For higher education productivity, five items are added in the questionnaire and measured on similar five points Likert scale. For the better understanding of respondents, questionnaire was divided into various sub sections covering the title of HR development indicators and higher education productivity factors as well. After developing the questionnaire, the selection of targeted sample was another significant decision under present study. For this purpose, employees from higher education in Indonesia are selected who are working in various departments with different managerial positions. A total sample of 138 respondents are selected as core respondents of interest with their random selection from various sub-department of higher education. For the analysis purpose, data was collected within a time span of one month and entered into the SPSS-22 and SMARTPLS 2.0. For better understanding, framework for factor analysis, and structural equation model (SEM) are developed and presented in the subsequent sections. Fig. 2 provides a better understanding for the selected latent indicators and relationship between the variables.

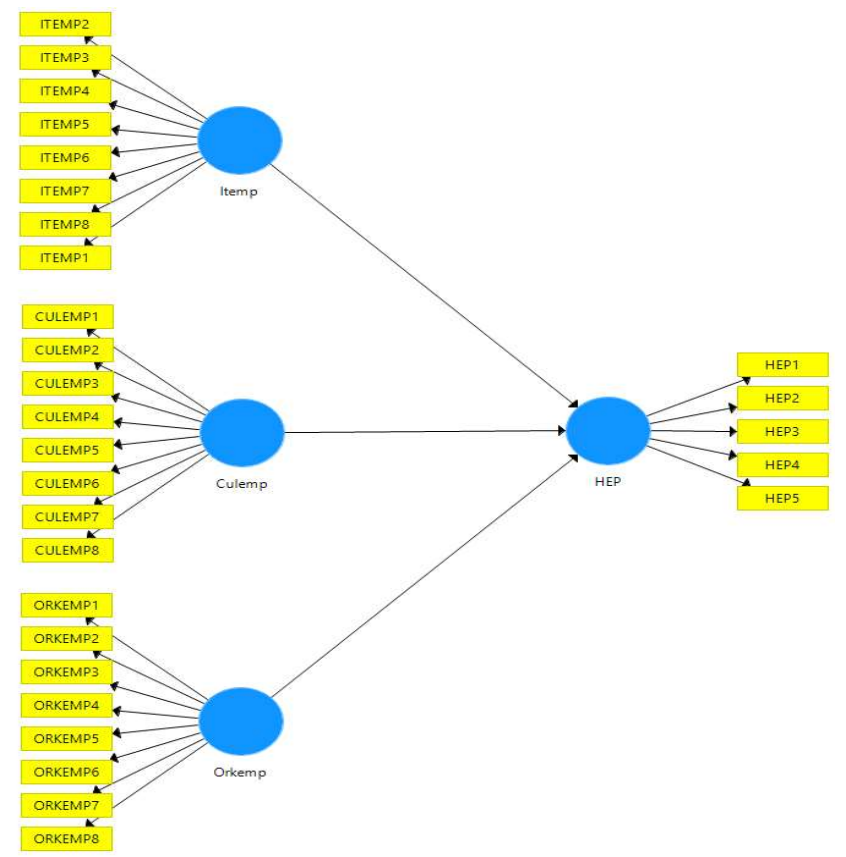

Fig. 2. Structural Model of the Study

Source: Authors 


\section{Results and Discussion}

As described earlier, the purpose of the present study is to examine the effect of human resources development on the productivity of higher education in the region of Indonesia. for this purpose, certain tests were also applied to examine the validity and reliability of the instrument which covers the value of Cronbach's alpha, average variance extracted and composite reliability. For the reliability of the questionnaire and selected items of both exogenous and endogenous variables, a questionnaire is supposed to be a good if the value of Cronbach's alpha is greater than .70. For average variance extracted or AVE, the cut point should be observed above .50 and for the composite reliability or CR, this value should be greater than the level of .70. For the first measure of instrumental reliability or CB value, all four variables are presented under Table 1. For cultural empowerment, overall value of $\mathrm{CB}$ is .822 , for information technology empowerment CB is .727, for organizational knowledge empowerment, CB score is .726 and finally for higher education empowerment or HEP, CB score is .822. All these values indicate that there is no problem for the reliability of the questionnaire as developed through selected items for each of the variables of the study. In addition, AVE is also calculated, which shows the convergent validity to understand the relationship between various items of the questionnaire. For checking the value of AVE threshold point is .50 and above. Table 1 shows that for both exogenous and endogenous variables, all are presenting the value of AVE above .50 and maximum of .644. These findings again supporting the argument that there is no problem for the validity of the questionnaire. The last indicator for checking the reliability of the questionnaire CR value is calculated and presented. A common notion for accepting the CR is that it must be greater that AVE. For all four latent variables, CR value is greater than .70, therefore defending the fact that there is no issue for the reliability for the developed instrument under present study.

Table 1

Model Fit Indices

\begin{tabular}{lccc}
\hline Variables & CB Alpha & Average Variance Extracted (AVE) & Composite Reliability \\
\hline CULEMP & 0.822 & 0.591 & 0.745 \\
HEP & 0.727 & 0.574 & 0.817 \\
ITEMP & 0.822 & 0.644 & 0.844 \\
ORKEMP & 0.726 & 0.600 & 0.870 \\
\hline
\end{tabular}

For the analysis purpose, in the very first step, variance inflation factor VIF test was applied to examine the tolerance level for various items of human development. VIF test indicates either there is a problem of higher interdependency between the selected items or not. Table 2 below presents the value of VIF and tolerance through dividing the VIF over 1. After the detailed examination of stated values under Table 1, it is observed that VIF for all the items is in range from 1 to 3 and the highest VIF is observed for ITEMP3; 2.669 and the lowest value was for ORKEMP8; 1.069. The mean score of VIF is 1.916, indicating that there is no problem of higher interdependency between the selected items of three exogenous variables of the study. For tolerance level, all the items have shown an above tolerance of .10, strengthen the argument that various items are statistically fit with reasonable level of correlation for the further analysis. Therefore, all three latent variables under the title of information technology empowerment (ITEMP), cultural empowerment (CULEMP) and organizational knowledge empowerment (ORKEMP) are observed as key determinant of higher education productivity in the region of Indonesia. For the consideration of various items in structural model of the study, factor analysis was performed, and their values are presented under Table 3. It is observed that for the cultural empowerment, factor loadings for each of the item was in range from .65 to .77, representing a reasonable level of factor loadings for the structural model of the study. All these loadings have an acceptable level of standard deviation with the T-statistics of above the threshold point of 1.96, which means that CULMP1 to CULMP 8 are statistically significant at 5 percent level, and 95 percent confidence level. 
Table 2

VIF and Tolerance level for selected items of exogenous variable (Human Development)

\begin{tabular}{lcc}
\hline \multicolumn{1}{c}{ Items } & VIF & $1 /$ VIF \\
\hline ITEMP3 & 2.669 & 0.375 \\
CULEMP5 & 2.558 & 0.391 \\
ITEMP5 & 2.542 & 0.393 \\
ORKEMP5 & 2.202 & 0.454 \\
CULEMP4 & 2.201 & 0.454 \\
ITEMP2 & 2.119 & 0.472 \\
ITEMP7 & 2.054 & 0.487 \\
ORKEMP3 & 2.048 & 0.488 \\
CULEMP7 & 2.033 & 0.492 \\
ITEMP1 & 1.975 & 0.506 \\
ORKEMP4 & 1.961 & 0.510 \\
ITEMP8 & 1.948 & 0.513 \\
CULEMP8 & 1.937 & 0.516 \\
CULEMP3 & 1.935 & 0.517 \\
ORKEMP6 & 1.892 & 0.529 \\
ORKEMP2 & 1.852 & 0.540 \\
CULEMP1 & 1.851 & 0.540 \\
CULEMP2 & 1.786 & 0.560 \\
ITEMP6 & 1.757 & 0.569 \\
ORKEMP1 & $\mathbf{1 . 6 6 8}$ & $\mathbf{0 . 6}$ \\
ORKEMP7 & 1.373 & 0.728 \\
CULEMP6 & 1.368 & 0.731 \\
ITEMP4 & 1.180 & 0.847 \\
ORKEMP8 & 1.067 & 0.937 \\
\hline Mean VIF & 1.916 &. \\
\hline
\end{tabular}

For the factor loadings of higher education productivity (HEP), five items are observed with the factor loadings of .670 for HEP1, .608 for HEP2, .772 for HEP3, .718 for HEP4, and .654 for HEP5 respectively. For the factor loadings for information technology empowerment, all factors are also presenting a good loading score and in range of .70-.80, respectively. For organizational empowerment, again the factor loadings are finally accepted at significant level of 5 percent.

Finally, for the discussion of research hypotheses, path coefficients, their standard errors, t-statistics and p-values are presented in Table 4. For the first research hypothesis, the impact of cultural empowerment on productivity of higher education is observed. The coefficient for HEP through CULEMP is .229 with the sample mean of .051 and standard deviation from the mean in the coefficient is .104. It means that CULEMP shows a positive influence on the value of HEP. The more the empowerment of human resources in higher education through cultural empowerment, the more the productivity of higher education. This effect is significantly accepted at 5 percent with the p-value of 0.000 and T-score of 0.202 . It means that there is a significant and positive influence of cultural development on the productivity of higher education in Indonesia. Through information technology empowerment of human resources in higher education, the impact on HEP is .831, which shows a positive influence. It means that empowerment of human through increasing their IT expertise has its direct influence on the value of higher education productivity in Indonesia. This effect is significant at 5 percent which means that, $\mathrm{H}_{2}$ will be accepted at 95 percent confidence level. For the third factor of organizational knowledge empowerment of the employees, coefficient is .309 and standard deviation of .083. It shows that the third factor of human empowerment also shows its significant and positive impact on HEP in Indonesia. To indicate the explanatory power of the model, R-square is .634, showing a reasonable level of explained variation in overall HEP. With the adjustment of sample size, adjusted value of R-square is .617. Fig. 3 provides the structural path of the model with their coefficients and loadings for each item of both exogenous and endogenous variables of the study. 
Table 3

Factor loadings, sample Mean, Standard Deviation and P value for the Factor loadings

\begin{tabular}{|c|c|c|c|c|c|}
\hline Items/Variables & $\begin{array}{c}\text { Original Sample } \\
(\mathrm{O})\end{array}$ & $\begin{array}{c}\text { Sample Mean } \\
(\mathrm{M})\end{array}$ & $\begin{array}{c}\text { Standard Deviation } \\
\text { (STDEV) }\end{array}$ & $\begin{array}{c}\text { T Statistics } \\
(|\mathrm{O} / \mathrm{STDEV}|)\end{array}$ & $\begin{array}{c}\mathrm{P} \\
\text { Values } \\
\end{array}$ \\
\hline CULEMP1 ŁCU- & 0.749 & 0.262 & 0.237 & 3.157 & 0.000 \\
\hline CULEMP2 $\leftarrow$ CU- & 0.733 & 0.242 & 0.148 & 4.940 & 0.000 \\
\hline CULEMP3 $\leftarrow$ CU- & 0.709 & 0.361 & 0.142 & 4.976 & 0.000 \\
\hline CULEMP4 Ł CU- & 0.772 & 0.362 & 0.358 & 2.154 & 0.024 \\
\hline CULEMP5 $\leftarrow$ CU- & 0.652 & 0.385 & 0.162 & 4.037 & 0.000 \\
\hline CULEMP6 $\leftarrow$ CU- & 0.725 & 0.355 & 0.271 & 2.675 & 0.008 \\
\hline CULEMP7 $\leftarrow$ CU- & 0.725 & 0.415 & 0.243 & 2.980 & 0.000 \\
\hline CULEMP8 $\leftarrow$ CU- & 0.708 & 0.336 & 0.301 & 2.357 & 0.000 \\
\hline $\mathrm{HEP} 1 \leftarrow \mathrm{HEP}$ & 0.678 & 0.656 & 0.132 & 5.154 & 0.000 \\
\hline HEP $2 \leftarrow$ HEP & 0.608 & 0.605 & 0.179 & 3.393 & 0.001 \\
\hline $\mathrm{HEP} 3 \leftarrow \mathrm{HEP}$ & 0.772 & 0.727 & 0.137 & 5.642 & 0.000 \\
\hline HEP4 $\leftarrow$ HEP & 0.718 & 0.673 & 0.166 & 4.322 & 0.000 \\
\hline HEP5 $\leftarrow$ HEP & 0.654 & 0.621 & 0.164 & 3.974 & 0.000 \\
\hline ITEMP2 $\leftarrow$ ITEMP & 0.788 & 0.501 & 0.264 & 2.985 & 0.026 \\
\hline ITEMP3 $\leftarrow$ ITEMP & 0.725 & 0.606 & 0.327 & 2.218 & 0.027 \\
\hline ITEMP4 « ITEMP & 0.746 & -0.014 & 0.255 & 2.929 & 0.005 \\
\hline ITEMP5 $\leftarrow$ ITEMP & 0.812 & 0.675 & 0.334 & 2.432 & 0.015 \\
\hline ITEMP6 $\leftarrow$ ITEMP & 0.740 & 0.612 & 0.290 & 2.555 & 0.011 \\
\hline ITEMP7 $\leftarrow$ ITEMP & 0.784 & 0.658 & 0.285 & 2.750 & 0.006 \\
\hline ITEMP8 $\leftarrow$ ITEMP & 0.698 & 0.583 & 0.269 & 2.592 & 0.010 \\
\hline ORKEMP1 $\leftarrow$ & 0.778 & 0.241 & 0.315 & 2.473 & 0.230 \\
\hline ORKEMP2 $\leftarrow$ & 0.851 & 0.263 & 0.276 & 3.085 & 0.000 \\
\hline ORKEMP3 $\leftarrow$ & 0.842 & 0.289 & 0.291 & 2.891 & 0.001 \\
\hline ORKEMP4 $\leftarrow$ & 0.781 & 0.266 & 0.305 & 2.563 & 0.005 \\
\hline ORKEMP5 $\leftarrow$ & 0.767 & 0.238 & 0.302 & 2.540 & 0.005 \\
\hline ORKEMP6 $\leftarrow$ & 0.750 & 0.255 & 0.373 & 2.011 & 0.015 \\
\hline ORKEMP7 $\leftarrow$ & 0.797 & 0.180 & 0.324 & 2.462 & 0.016 \\
\hline ORKEMP8 $\leftarrow$ & 0.726 & 0.068 & 0.285 & 2.546 & 0.005 \\
\hline ITEMP1 $\leftarrow$ ITEMP & 0.608 & 0.505 & 0.309 & 1.969 & 0.049 \\
\hline
\end{tabular}

Table 4

Path Coefficients

\begin{tabular}{lccccrr}
\hline & $\begin{array}{c}\text { ORIGINAL } \\
\text { SAMPLE }(\mathrm{O})\end{array}$ & $\begin{array}{c}\text { SAMPLE } \\
\text { MEAN (M) }\end{array}$ & $\begin{array}{c}\text { STANDARD DE- } \\
\text { VIATION } \\
(\text { STDEV })\end{array}$ & $\begin{array}{c}\text { T STATISTICS } \\
(\mid \mathrm{O} / \text { STDEV } \mid)\end{array}$ & P VALUES & Result \\
\hline $\begin{array}{l}\text { CULEMP } \rightarrow \\
\text { HEP }\end{array}$ & 0.229 & 0.051 & 0.104 & 2.202 & 0.000 & Accepted \\
$\begin{array}{l}\text { ITEMP } \rightarrow \text { HEP } \\
\text { ORKEMP } \rightarrow\end{array}$ & 0.831 & 0.085 & 0.184 & 4.513 & 0.000 & Accepted \\
HEP & 0.309 & 0.031 & 0.083 & 3.730 & 0.000 & Accepted \\
\hline
\end{tabular}

R-Square $=0.634$

Adjusted R-square $=.617$

Based on the above findings, following research hypotheses are finally accepted:

$\mathrm{H}_{1}$ : Empowerment of human resources in terms of information technology is beneficial to increase the productivity the of higher education.

$\mathrm{H}_{2}$ : Empowerment of human resources in terms of cultural dimensions is beneficial to increase the productivity the of higher education.

$\mathrm{H}_{3}$ : Empowerment of human resources in terms of organizational knowledge is beneficial to increase the productivity the of higher education. 


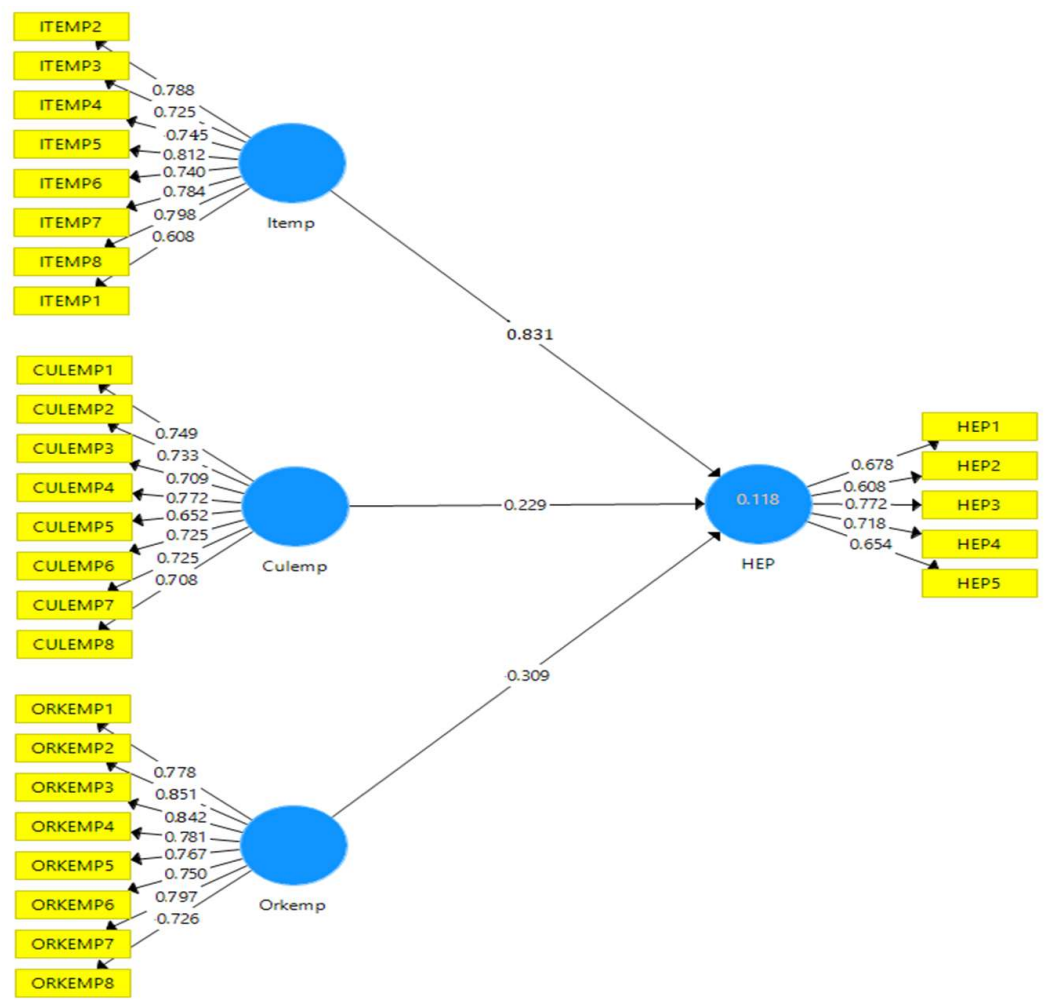

Fig. 3. Structural Model with path output (Human empowerment and higher education productivity) Source: Authors

\section{Conclusions}

This study has empirically investigated the productivity of Muhammadiyah higher education while taking the human resource empowerment indicators like information technology, cultural dimension and organizational knowledge as the key exogenous variables of the study. Primary data from various respondents of Muhammadiyah higher education was collected for the structural model of the study. Findings of the study have indicated the key factors to significantly contributes towards the productivity of Muhammadiyah higher education are the human resource empowerment through cultural dimensions, information technology and organizational knowledge with direct and significant influence under full sample of the study. However, this study is limited by various perspectives. At first, data is collected from the region of Indonesia through employees of Muhammadiyah higher education only with limited generalizability of the findings. Second, the study has not discussed the combine effect of human resource empowerment on overall productivity of Muhammadiyah higher education but with individual dimensions like cultural, information technology and knowledge factors. The findings can be meaningful to boost the performance and productivity of higher education while understanding its structural relationship between human resources development. Managerial implications of this study also provide the fact that for the improved organizational performance in terms of productivity, business firms can adopt the present conceptual model for better understanding.

\section{Acknowledgement}

The authors would like to thank the anonymous referees for constructive comments on earlier version of this paper. 


\section{References}

Abankina, I., Abankina, T., Filatova, L., Nikolayenko, E., \& Seroshtan, E. (2012). The effects of reform on the performance of higher education institutions. Journal of Applied Research in Higher Education, 4(1), 23-41.

Akbari, N., \& Ghaffari, A. (2017). Verifying relationship of knowledge management initiatives and the empowerment of human resources. Journal of Knowledge Management, 21(5), 1120-1141.

Amar, F., \& Setiawan, E. (2018). MODEL DAKWAH MUHAMMADIYAH DI DAERAH TERPENCIL, TERLUAR DAN TERDALAM: STUDI KASUS DI KALIMANTAN TENGAH. Paper presented at the Prosiding Kolokium Doktor dan Seminar Hasil Penelitian Hibah.

Andriani, Y., Trisnamansyah, S., \& Iriantara, Y. (2019). Peran dan Fungsi Majelis Pendidikan Dasar dan Menengah Dalam Meningkatkan Mutu Pendidikan Sekolah Menengah Atas Muhammadiyah di Kabupaten Bandung. Nusantara Education Review, 1(2), 81-88.

Bolli, T., \& Farsi, M. (2015). The dynamics of productivity in Swiss universities. Journal of Productivity Analysis, 44(1), 21-38.

Crookes, A. (2017). Educating society's future PR practitioners: An exploration of 'Preparedness' as a qualitative indicator of higher education performance How Strategic Communication Shapes Value and Innovation in Society (pp. 1-21): Emerald Publishing Limited.

Daszkiewicz, N., Korol, T., Lechman, E., Olczyk, M., Starnawska, M., \& Wolszczak-Derlacz, J. (2008). Konkurencyjność: poziom makro, mezo i mikro.

Fernandes, S., \& Fernandes, A. A. R. (2018). The mediating effect of service quality and organizational commitment on the effect of management process alignment on higher education performance in Makassar, Indonesia. Journal of Organizational Change Management, 31(2), 410-425.

Flegg, A.-T., Allen, D., Field, K., \& Thurlow, T. (2004). Measuring the efficiency of British universities: a multi-period data envelopment analysis. Education economics, 12(3), 231-249.

Flegg, A., Allen, D., Field, K., \& Thurlow, T. (2003). Measuring the efficiency and productivity of British universities: an application of DEA and the Malmquist approach. University of the West of England, Department of Economics, series Discussion Papers, 304.

Halkos, G. E., Tzeremes, N. G., \& Kourtzidis, S. A. (2010). An application of statistical interference in DEA models: An analysis of public owned university departments' efficiency: EERI Research Paper Series.

Haseeb, M., Hussain, H. I., Ślusarczyk, B., \& Jermsittiparsert, K. (2019). Industry 4.0: A solution towards technology challenges of sustainable business performance. Social Sciences, 8(5), 154.

Hill, R., \& Stewart, J. (2000). Human resource development in small organizations. Journal of european industrial training, 24(2/3/4), 105-117.

Parteka, A., \& Wolszczak-Derlacz, J. (2013). Dynamics of productivity in higher education: CrossEuropean evidence based on bootstrapped Malmquist indices. Journal of Productivity Analysis, 40(1), 67-82.

RA, R. Y. S. (2006). Hubungan antara komitmen organisasi dan iklim organisasi dengan kepuasan kerja karyawan Universitas Muhammadiyah Surakarta. Benefit: Jurnal Manajemen dan Bisnis, 9(2), 120128.

Rabasa, A. (2005). Islamic Education in Southeast Asia. Current trends in Islamist ideology, 2, 97-108.

Sukirno, D., \& Siengthai, S. (2011). Does participative decision making affect lecturer performance in higher education? International Journal of Educational Management, 25(5), 494-508.

Ulutaş, B. H. (2011). assessing the Relative Performance of University departments: teaching vs. Research. Ekonometri ve Ïstatistik e-Dergisi(13), 125-138.

Visbal-Cadavid, D., Martínez-Gómez, M., \& Guijarro, F. (2017). Assessing the efficiency of public universities through DEA. A case study. Sustainability, 9(8), 1416.

Wolszczak-Derlacz, J. (2018). Assessment of TFP in European and American higher education institutions-application of Malmquist indices. Technological and Economic Development of Economy, 24(2), 467-488. 
Worthington, A. C., \& Lee, B. L. (2008). Efficiency, technology and productivity change in Australian universities, 1998-2003. Economics of education review, 27(3), 285-298.

Zain, A., Yusuf, M., \& Fuadi, M. (2017). INTERNALISASI NILAI-NILAI MODERNITAS DALAM GERAKAN DAKWAH ORGANISASI MUHAMMADIYAH DI ACEH. Al-Idarah: Jurnal Manajemen dan Administrasi Islam, 1(1), 17-42.

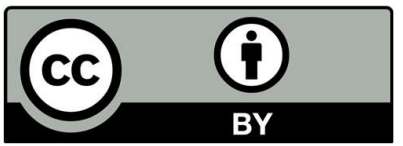

(C) 2019 by the authors; licensee Growing Science, Canada. This is an open access article distributed under the terms and conditions of the Creative Commons Attribution (CCBY) license (http://creativecommons.org/licenses/by/4.0/). 